\section{IJ§ER}

ISSN: 2149-5939
International Journal of Social Sciences and Education Research

Online, http://dergipark.gov.tr/ijsser

Volume: 3(4), 2017

\title{
Union Organization Right of the Employees of Security General Directorate in Turkey in line with the similar decisions of European Court of Human Rights
}

\author{
M. Engin Sanal ${ }^{1}$
}

Received Date: 01 / 04 / 2017

Accepted Date: 14 / 06 / 2017

\begin{abstract}
The union organization of the security forces constitutes an exceptional issue in the world. In general, international contracts liberalize the countries in domestic law regimes. For the security personnel, all the service classes working in the security organization and all private security officers working in the public institutions should be taken under the scope of the union organizing prohibition by going out of the field which the international contracts have left to the domestic law regimes and they should not be harmful to the right of trade union organization which is one of the indispensable requirements of the democratic society order in Turkey. As a matter of fact, the Constitutional Court has canceled a part of the legal regulation in contradiction with the Constitution.
\end{abstract}

Keywords: Union organization right, Employees of security, European Court Of Human Rights, The Constitutional Court of the Republic of Turkey

\section{Introduction}

The unionization of the armed forces and constables constitutes an exceptional issue in the world. In general, international conventions leave the regulation of the union rights of these two groups to countries and do not make binding regulations for the parties.

The common implementation in the world is to exclude those who are in charge of armed forces, police, law enforcement officers and management and supervision from the scope of the freedom of unionization. While the ban on the members of the armed forces is more comprehensive, the rights of the organization of constables (policemen) are known more widely in the world. Especially after the 1960s, the tendency to organization has increased in the public sector with the popularization of the collective labour agreements. While until the 1960s, even in some European countries, only labour unions used to come to mind when unionism was mentioned, nowadays, organization in public has considerably left the private sector behind in countries such as the United Kingdom, the USA, Northern countries, Argentina, Cuba, and Brazil. There is a similar picture in Turkey as well (Kutal, 2013). The change in the organization of public officials is also reflected on the police. For example, police organizations established before the 1960s in the USA used to come to the forefront more as solidarity or charity associations rather than labour organization (Kadlec, 2003). The police in the USA obtained an increase in their wages between the rates of 3.9 percentage and 6.4 percentage thanks to the police organizations in the 1980s (Bartel \& Lewin, 1981). However, the police constitute the second largest group excluded from the scope. The USA, Germany, Austria, Belgium, Denmark and Norway can be indicated as the examples of the countries that recognize the right to establish

\footnotetext{
${ }^{1}$ Assoc. Prof. Dr., Trakya University, Faculty of Economics \& Administrative Sciences, Edirne/TURKEY,
} menginsanal@gmail.com 
Sanal, M.E. (2017). Union Organization Right of the Employees of Security General Directorate in Turkey in line with the similar decisions of European Court of Human Rights. International Journal of Social Sciences and Education Research, 3(4), 1184-1193.

unions to the police in the world. On the other hand, Malaysia and Mexico can be indicated as the examples of the countries that prohibit union rights. Moreover, Cameroon, Malaysia, and Pakistan are the countries that set this restriction on the prison staff (Bibilik, 2008).

Despite this basic picture in the world, an inseparable part of human rights is the freedom of organization. Human rights can be neither created nor denied by governments, employers or other organs of the society. Hence, it is inevitable that the police have a secured right to organize (Adams, 2008). Accordingly, Article 32 of the European Code of Police Ethics acknowledges that the police can organize in order to protect their economic and social rights just as all public officials (Committee of Ministers of the Council of Europe, 2001).

Not only the police but all public officials were banned from organizing up to 2001 in Turkey, which constitutes the main subject of the study. Subsequently, the Government Employee Unions and Collective Bargaining Law No. 4688 accepted in 2001 gave public officers the right to organize in the general sense, but the police were within the scope of Article 15 in which those excluded from the scope of this right were listed. The lawsuit process started with the application of Emniyet-Sen, which was aimed to be established in order to organize the police despite this ban, to the Governorship of Ankara on 9 November 2012. Then, many administrative interventions were made on the subject (Gülmez, 2016). A case was filed at Ankara 9th Labour Court for the closure of Emniyet-Sen, which was established problematically, and despite its performing approximately seven activities. The court took the case to the Constitutional Court on the grounds that the right to unionize was a fundamental right and banning all law enforcement officers from this would be against the Constitution of the Republic of Turkey. The Constitutional Court partially restricted the scope of the ban with the decision it made.

\section{Security Forces' Right to Organize in International Conventions}

The most important international conventions aimed at securing the freedom of individual association is Convention No. 87 on Freedom of Association and Protection of the Right to Organise accepted by the International Labour Organization (ILO) in 1948, the Right to Organise and Collective Bargaining Convention No. 98 accepted in 1949, and Convention No.151 on the Determination of Employment Conditions in the Public Sector accepted in 1978. These conventions accepted by the ILO were also determinative for the International Convention on Economic, Social and Cultural Rights and the International Covenant on Civil and Political Rights accepted by the United Nations in 1966, and the articles regulating the right to organise in the European Social Charter and the revised European Social Charter included in the law of the European Union to a great extent.

In conventions No. 87 and 98 accepted by the ILO, whether and how armed forces and constables could benefit from these rights were left to national regulations (International Labour Organization, 1948 \& International Labour Organization, 1949). While the ILO regulates the right of public officers to unionize with convention No. 151, it states to what extent the assurance provided to armed forces and constables, in addition to senior officials whose duties are accepted to be policy determination and management works to be monitored or those who perform duties of highly confidential nature will be applied will be determined by national laws (International Labour Organization, 1978). 
Sanal, M.E. (2017). Union Organization Right of The Employees of Security General Directorate in Turkey in line with the similar decisions of European Court of Human Rights. International Journal of Social Sciences and Education Research, 3(4), 1184-1193.

Article No. 20 of the United Nations Universal Declaration of Human Rights accepts that everyone has the right to hold peaceful meetings, form and join associations, and no one can be forced to become a member of an association (United Nations, 2017). Article 23 of the Declaration gives everyone the right to establish unions and freely become a member to them with the expression that "everyone has the right to establish or become a member of unions in order to protect one's interest" (United Nations, 2017).

Consequently, apart from the UN Universal Declaration of Human Rights, and in addition to conventions No. 87, 98 and 151 of the ILO, Article eight of the International Convention on Economic, Social and Cultural Rights and Article twenty-two of the International Covenant on Civil and Political Rights accepted by the UN, Article eleven of the European Convention on Human Rights and Article five of the European Social Charter and the revised European Social Charter accepted by the European Council give employees the freedom of individual association in the general sense, however, they set the domestic legal systems of the countries free in the regulation of whether and how armed forces and security members can benefit from these rights (European Court of Human Rights, 2016; Şen, 2003 \& Gülmez, 2006).

\section{Right to organise of Security Forces in the Turkish Labour Law Legislation}

Article fifty-one of the Constitution of the Republic of Turkey secures that employees and employers can establish unions and upper organizations without getting prior permission, they can freely become members of these unions, and drop out of membership. The second paragraph of the same article states that the right to establish unions can only be restricted for reasons of national security, public order, preventing the commitment of a crime, and protecting the general health and general moral, and others' rights and freedom. Hence, the individual and collective freedom of association were guaranteed in the constitution in general.

According to Article 21 of the Trade Union Act No. 2821 in its first state that was in force between 1983 and 2012 and regulated the organisation of workers, it was regulated that soldiers, and inspectors, controllers and directors and other managers equal to this and at higher levels working in administration, institutions, foundations, banks and insurance companies, those who work in religious and worship services, students and private school teachers could not become members of unions. Over time, the qualification of those who could not be joint union members decreased and only soldiers were left prohibited. No employee that cannot be a member of labour unions is specified in the Trade Unions and Collective Labour Agreement No. 6356.

Article No. 7 of Law No. 624 concerning trade unions of public officials that first regulated the unionization of public officials and was accepted in 1965 regulates those who cannot be members of these trade unions. According to the relevant article, soldiers and officers of the Ministry of National Defence and the General Secretariat of the Council of National Defence and officials of the General Commandership of Gendarmerie and members of the Security Organisation and the public officials who are allowed to carry firearms and use force by law are also within the scope of this ban. With the closure of all unions of public officials as a result of the "military memorandum" on 12 March 1971 in Turkey, the Law lost its field of practice.

Article 15 of Law No. 4688 that regulated the unionization of public officials and that was accepted in 2001 banned the members of the armed forces (a. 15/f), public officials working in 
Sanal, M.E. (2017). Union Organization Right of the Employees of Security General Directorate in Turkey in line with the similar decisions of European Court of Human Rights. International Journal of Social Sciences and Education Research, 3(4), 1184-1193.

penitentiary institutions (a. 15/k), personnel within the security services class and other service classes working in the law enforcement agency and private security personnel of public institutions and organizations from unionization, in addition to many public officials, as it was first enacted (a. 15/j). Especially the fact that the personnel included in other service classes working in the law enforcement agency, in addition to the security services class that constitutes the subject of our study, were within the scope of the ban led to discussions in the doctrine and practice. The fact that many public officials are deprived of unionization rights since Article 15 of Law No. 4688 regulating that public officials cannot be members of trade unions is very comprehensive is controversial, and it is subject to litigation in the Constitutional Court. It is also observed that the legal regulation in question is against international conventions accepted by the Republic of Turkey.

\section{A Lawsuit Brought to the Constitutional Court for Article 15 of Law No. 4688}

A lawsuit was brought to the Constitutional Court in 2013 by the Ninth Labour Court of Ankara on grounds that the fact that all security services class members working in the central and provincial organization of the General Directorate of Security and employees in all other service classes in the law enforcement agency were within the scope of the ban indicated in Article 15 of Law No. 4688 was against the Constitution.

In the case opened at the request of the determination that the trade union established with the aim of protecting the economic and social rights and interests of all security services class members working in the central and provincial organization of the General Directorate of Security and personnel working in all other service classes in the law enforcement agency was null and void, the Ninth Labour Court of Ankara applied to the Constitutional Court with the request for the cancellation of Article 15 of the Public Officers' Unions and Collective Bargaining Law No. 4688 by putting forth its violation of point (j) of the first paragraph replaced with point (b) of Article No. 31 of Law No. 6289, and Articles 5, 11, 13 and 51 of the Constitution.

\subsection{Cause of Action}

In the cause of action, after emphasising that Article 51 of the Constitution gave employees and employers the right to establish trade unions as a fundamental right, and that restriction was an extraordinary arrangement, pursuant to the relevant article of the Constitution, it was stated that the Public Officers' Unions and Collective Bargaining Law No. 4688 was implemented and those who could not become members of the public official's trade unions were listed in Article 15 of this Law, and it was put forth that acknowledging that the personnel included in the security services class and other service classes working in the law enforcement agency in Article $15 / \mathrm{j}$ in this ranking could not be members of the trade union was against Article 51 of the Constitution, and also the International Labour Organization's conventions No. 87 and 151 that became rules of the domestic law on 25.11.1992.

In the cause of action, while it was stated in Article nine of the ILO convention No. 87 that the right of the armed forces and security members to organize could be regulated by national legislation, the states were given the right to "restrict" this right with the regulation to what extent the assurances provided for in the Convention would be applied to the armed forces and police would be determined by national laws in Article one of the ILO convention No. 151. 
Sanal, M.E. (2017). Union Organization Right of The Employees of Security General Directorate in Turkey in line with the similar decisions of European Court of Human Rights. International Journal of Social Sciences and Education Research, 3(4), 1184-1193.

Therefore, both the regulation in Article 51 of the Constitution and the regulations in the ILO conventions No. 87 and 151 are exactly the same, and the right to establish trade unions and become members was regarded as a fundamental right, and the basis of restricting it according to the domestic law was introduced. According to the Constitution, it is obvious that this right can be restricted on the grounds of national security, public order, prevention of crime, protecting general health and general morality, and others' rights and freedoms, and this restriction must be performed without touching the essence of the right as it is stated in Article 13 of the Constitution.

"Nevertheless, Article 15/j of Law No. 4688 that constituted the basis of the case did not make any restriction and did not give the employees of the law enforcement agency the right to establish trade unions in such a way that it completely removed the essence of the right. While this regulation is against Articles 11, 13 and 51 of the Constitution, it is also against Article 5 that regulates the aims and duties of the state because the aim of the state of the Republic of Turkey is to try to remove the political, economic and social barriers that limit the fundamental rights and freedoms of individuals in such a way that does not match the principles of the social law state and justice, and prepare the necessary conditions for the material and moral development of people. While the aim of the state in its simplest state is to develop the fundamental rights and freedoms and remove the barriers in front of them, it is certain that eliminating a basic right completely for security members is against the Constitution." (Türkiye Cumhuriyeti Anayasa Mahkemesi, 2013a).

"The fact that individuals are not allowed to establish trade unions at all just because they work in the law enforcement agency or carry firearms has no explanation in terms of modern democracies. In modern democracies, security members can also establish trade unions in order to protect and develop their economic and social rights and interests to the extent that their fundamental rights and freedoms allow. Indeed, it is for certain that the police are given the right to establish trade unions in many countries, and especially European countries. This obviously does not disrupt the discipline and order-command chain of the profession, as well as it does not hinder the defence and security of the country." (Türkiye Cumhuriyeti Anayasa Mahkemesi, 2013a).

It was put forth that banning the whole occupational group from the right to organize, which was regulated as a fundamental right in Article 51 of the Constitution, would turn the employees in this profession into "modern slaves", and this was not acceptable for a democratic society. It was argued that the restriction here should be regarded as excluding certain very special units within an occupational group - for example, the members of the National Intelligence Organisation - from the scope.

Furthermore, in its decision No. 28602/95 dated 21.5.2006 between Haber-Sen and Turkey, the European Court of Human Rights handed down a decision against Turkey by finding that eliminating the right to establish a trade union for a whole occupational group was unjust. Similarly, it is for certain that the ECHR accepts the principle that it is possible for the police to establish trade unions in the case No. 4464/70 dated 27.10.1975 between Belgium's Police Union and Belgium. 
Sanal, M.E. (2017). Union Organization Right of the Employees of Security General Directorate in Turkey in line with the similar decisions of European Court of Human Rights. International Journal of Social Sciences and Education Research, 3(4), 1184-1193.

"Consequently, the following decision was made by reaching the conclusion that using the authority given to the lawmaker in the sense of "restricting" the right to establish trade unions with the Constitution as total banning with Article 15/j of Law No. 4688 was against Articles 5, 11, 13 and 51 of the Constitution." (Türkiye Cumhuriyeti Anayasa Mahkemesi, 2013a).

\subsection{Decision of the Constitutional Court}

The Constitutional Court handed down its decision by examining the expressions of "Security services class..." and "...the personnel included in other service classes working in the law enforcement agency" in Point j, Article 15 of Law No. 4688 separately.

\subsubsection{Examination of the Expression of "Security services class" in Point j, Article 15 of Law No. 4688}

According to Article 36 of the Civil Servants Act No. 657, the security services class incorporates downtown and district watcher, police, sergeant, commissioner, chief inspector, safety inspector, police inspector, chief police officer, chief of police and security members who have gained the title of the chief of police according to special laws.

After this determination, in the decision of the Constitutional Court, Article 51 of the Constitution emphasizes that the right of association is a part of the freedom of organization, which is the basis of a democratic society, in addition to securing the unionization right of not only workers but all employees. However, the right to establish trade unions is not an absolute right, and it can be restricted by law pursuant to paragraph two, Article 51 of the Constitution for reasons of national security, public order, preventing the commitment of crime, and protecting the general health and general moral, and others' rights and freedoms. On the other hand, paragraph five of the same article incorporates the provision that "the scope, exceptions and limits of the rights of the public officers who are not workers in this field are regulated by law in accordance with the quality of the service they provide", thereby, making it possible to narrow or limit the scope of this right or prohibit the use of this right for certain public officers apart from the general reasons for restriction in paragraph two.

Furthermore, internal security is a public service of vital importance in terms of ensuring the public order, which requires a strict hierarchical discipline and authorizes the use of violence when necessary. The disruption of this service may lead to losses that are hard and impossible to compensate in terms of the public order. Indeed, with Article 9 of the ILO Convention No. 87 concerning Freedom of Association and Protection of the Right to Organise, which was found suitable to being approved by Law No. 3847 dated 25.11.1992 and which secured the freedom of all employees to establish trade unions and become members of trade unions in principle, it was stated that the extent of application of the assurances provided for in the Convention to the members of the armed forces and the police would be determined by the national legislation, and it gave the party states discretion regarding the right of establishing trade unions by the members of the armed forces and law enforcement officers.

It is obvious that the members of the security services class are banned from establishing trade unions and becoming members of trade unions with the legal regulation in question. It is understood that this ban is based on protecting the discipline and hierarchic order that are required to dominate the internal security services. 
Sanal, M.E. (2017). Union Organization Right of The Employees of Security General Directorate in Turkey in line with the similar decisions of European Court of Human Rights. International Journal of Social Sciences and Education Research, 3(4), 1184-1193.

To this end, there is no doubt that the special reasons for restriction specified in Article 51 of the Constitution are adhered to in restricting the right to establish trade unions by the members of the security services class, and this restriction is based on a legitimate aim. Nevertheless, it is also obvious that the phenomenon of unionization, which is regarded to be necessary in terms of ensuring social justice, has the potential to affect the discipline and hierarchical order that must exist in the public sector. The superior public interest in maintaining the democratic social order makes the potential of unionism to affect the discipline non ignorable in terms of the professions based on discipline, and it can form a justifiable basis for prohibiting unionism in these professions.

For these reasons, the Constitutional Court decided that the legal regulation in question was not against Articles 13 and 51 of the Constitution (Türkiye Cumhuriyeti Anayasa Mahkemesi, 2013 b).

However, in addition to Article 32 of the European Code of Police Ethics mentioned in the introduction section, in the decision made by the European Social Rights Committee on 21 May 2002 regarding the application made by the European Council of Police Unions against Portugal, it was concluded that Article 5 of the European Social Charter could limit the police's right to establish unions, but it could not eliminate it completely.

Although Turkey signed the European Social Charter by making reservation to Article 5, the European Court of Human Rights decided against Turkey in a decision it made on 21 May 2006, by finding the total elimination of the right to establish trade unions for a whole occupational group unjust (European Court of Human Rights, 2006). In a decision made on 12 November 2008, the European Court of Human Rights also did not accept Turkey's objection regarding the fact that the international conventions Turkey did not approve could not be applied to Turkey (European Court of Human Rights, 2008).

Therefore, this decision made by the Constitutional Court in line with the European Social Charter and the decisions made by the European Court of Human Rights in this respect and regarding Turkey is controversial. This decision contradicts the principles of the "requirements of the democratic social order" and "proportionality" that are two main criteria in the cases brought before the Constitutional Court.

4.2.2. Examination of the Expression "....and the personnel included in other service classes working in the law enforcement agency" in Point j, Article 15 of Law No. 4688

According to the Constitutional Court, with the expression included in the rule, which is subject of objection, the unionization of the civilian personnel who provide certain technical and logistic services that do not require the use of firearms, apart from the members of the security services class working in the law enforcement agency, is also banned in order to protect the discipline and hierarchical order.

Internal security services, of which steady fulfillment is indispensable for the sake of ensuring the public order, require the members of the security services class that is the main element of this service to work based on a strict discipline and hierarchical order. Therefore, the banning of their establishing trade unions can be regarded as a legitimate and necessary precaution for the sake of the democratic social order in order to prevent any damage to the discipline between 
Sanal, M.E. (2017). Union Organization Right of the Employees of Security General Directorate in Turkey in line with the similar decisions of European Court of Human Rights. International Journal of Social Sciences and Education Research, 3(4), 1184-1193.

the members of the security services class. Nevertheless, the effect that unionization will create on the working discipline of the civilian personnel performing duties restricted to certain technical and logistic services, who are not the main element of the internal security services, does not require their deprivation of the right to establish trade unions.

The disruptions that may occur in these services due to the discipline's weakness do not cause losses that are hard and impossible to compensate. On the other hand, it cannot be said that depriving the civilian personnel of the right to establish trade unions for reasons of the police discipline that is valid for the members of the security services class who are directly involved in internal security services is a useful means of achieving the aim of ensuring the public order by the prohibition of establishing trade unions for them, along with its not reconciling with the requirements of the democratic social order (Türkiye Cumhuriyeti Anayasa Mahkemesi, 2013 b).

Here, the Constitutional Court also approaches the subject in terms of the principle of proportionality. Proportionality reflects the relationship between the purposes of restriction of fundamental rights and freedoms and the means of restriction. The control of proportionality is controlling the means selected to achieve this aim starting from the aim that is desired to be achieved. Therefore, it must be assessed whether the rule is convenient, necessary and proportionate for achieving the targeted aim.

In this case, banning the civilian personnel working in the law enforcement agency from establishing trade unions is a legitimate and proportionate intervention in terms of the democratic social order.

Indeed, the judicial opinion of the European Court of Human Rights is also in this direction, and according to the last sentence of paragraph two, Article 11 of the European Convention on Human Rights regulating the "Right to Organise", legitimate restrictions can be introduced to the right of public officials working in the administrative mechanism of the state to establish trade unions, only in the presence of persuasive and compulsory reasons.

In line with the approach of the Constitutional Court, the European Court of Human Rights accepted the existence of police unions in its decisions regarding the National Union of Belgian Police on 27 October 1975, the police union in Slovakia on 25 September 2012, etc. (European Court of Human Rights, 1975 and European Court of Human Rights, 2012). Similarly, the European Social Rights Committee acknowledged that the European Council of Police Trade Unions (CESP) was right against the French government on 5 March 2014 (European Committee of Social Rights, 2014).

For these reasons, the Constitutional Court canceled the expression " ....and the personnel included in other service classes working in the law enforcement agency" in the rule, which is a subject of objection, on the grounds that it is against Articles 13 and 51 of the Constitution. This is a sound decision.

\section{Conclusion}

While lifting the ban on unionization for "... and the personnel included in other service classes working in the law enforcement agency" in Point j, Article 15 of Law No. 4688 with the decision made by the Constitutional Court on 29.01.2014 and published in the Official Gazette 
Sanal, M.E. (2017). Union Organization Right of The Employees of Security General Directorate in Turkey in line with the similar decisions of European Court of Human Rights. International Journal of Social Sciences and Education Research, 3(4), 1184-1193.

No. 28999 of 13.05.2014 is rightful, deciding to maintain the ban for the "Security services class..." in Point j, Article 15 of Law No. 4688 is controversial.

Just as in the justifications of dissenting votes, while the international conventions indicate that the right to unionize can be restricted for the members of the armed forces and security, it is obvious that especially security members cannot be fully deprived of this right.

In this regard, let alone the ILO conventions signed by Turkey, the fact that Turkey signed the European Social Charter alone introduces its responsibilities in this respect because although Turkey accepted the convention by making a reservation to Article 5 regarding the right to organise, it is bound with this article pursuant to the decision made by the European Court of Human Rights in 2008. Furthermore, it is not possible to overcome this with the domestic law regulations of Turkey since the following expression was added to Article 90 of the Constitution of the Republic of Turkey with a change made in 2004: "the provisions of international treaties shall be taken as a basis in disputes that may arise when international treaties and laws contain different provisions on the same subject regarding the fundamental rights and freedoms duly put into effect." According to this arrangement, the European Social Charter is a duly signed international convention, and it is above the rules of the domestic law.

Restrictions can be introduced to the right of unionization for certain reasons. Social and economic conditions of countries can be determinative in this respect. However, the generalization of these bans or their covering a whole occupational group is controversial and does not comply with a democratic social structure.

\section{References}

Adams, Roy, J. (2008). The human right of police to organize and bargain collectively. Police Practice and Research, 9 (2), 165-172.

Bartel, A. \& Lewin, D. (1981). Wages and unionism in the public sector: the case of police. Review of Economics \& Statistics, February 1981. Vol. 63. 53 - 59.

Bibilik, Erkan. (2008). Memur sendikacllı̆ğ ve toplu görüşme hakkl, Ankara: Yüksek Lisans Tezi.

Committee of Ministers of the Council of Europe. (2001). European code of police ethics. http://www.coe.int/ViewDoc.jsp?id=223251

European Committee of Social Rights. (2016) Avrupa insan hakları sözleşmesi. http://www.cte.adalet.gov.tr/menudekiler/uluslararasi/aihs.pdf.

European Committee of Social Rights. (2014).European council of police trade unions (CESP) v. France. Complaint No. 101/2013.

European Court of Human Rights. (1975). Case of national union of Belgian police v. Belgium. Application no. 4464/70.

European Court of Human Rights. (2006). case of Tüm Haber - Sen and Çınar v. Turkey. Application no. $28602 / 97$.

European Court of Human Rights. (2008). Case of Demir and Baykara v. Turkey. Application no. $34503 / 95$

European Court of Human Rights. (2012). Case of trade union of the police in the Slovak Republic and others v. Slovakia. Application no. 11828/08.

Gülmez, M. (2006). Sendikal haklarda uluslararası hukuka ve Avrupa Birliğine uyum sorunu. Ankara: Belediye-İş Yayınları. 
Sanal, M.E. (2017). Union Organization Right of the Employees of Security General Directorate in Turkey in line with the similar decisions of European Court of Human Rights. International Journal of Social Sciences and Education Research, 3(4), 1184-1193.

Gülmez, M. (2016). Polisiye bir sendikalaşma öyküsü. Karatahta İş Yazıları Dergisi, Sayı 4. 175-222.

International Labour Organization. (2017). Freedom of association and protection of the right to organise convention. 1948, no.87. http://www.ilo.org.

International Labour Organization. (2017). Right to organise and collective bargaining convention. 1949, no.98. http://www.ilo.org.

International Labour Organization. (2017). Labour relations (public service) convention. 1978, no.151. http://www.ilo.org.

Kadlec, C. (2003). Police employee organizations. Policing: An International Journal of Police Strategies \& Management, 26 (2). 341-351.

Kutal, M. (2013). Beşinci Sosyal Haklar Uluslararası Sempozyumu, Kamu görevlilerinin örgütlenme ve toplu pazarlık hakları (157-178), İstanbul, Petrol-İş Yayı̀n No. 118,.

Şen, M. (2003). Türkiye cumhuriyeti’nin onayladığ iş ve sosyal güvenlik hukuku alanındaki çok taraflı uluslararası sözleşmeler. Ankara: TÜHİS Yayınları.

Türkiye Cumhuriyeti Anayasa Mahkemesi. (2013a). Dava dilekçesi 2013/1, http://www.anayasa.gov.tr/Kararlar/GenelKurul/Dava_Dilekcesi/2014-161.pdf.

Türkiye Cumhuriyeti Anayasa Mahkemesi. (2013b). Anayasa mahkemesi kararı. 2014/18. http://kararlaryeni.anayasa.gov.tr.

United Nations. (2017). Universal declaration of human rights. www.un.org. 